\title{
Ecosystem service trade-offs and synergies misunderstood without landscape history
}

\author{
Stephanie A. Tomscha ${ }^{1}$ and Sarah E. Gergel ${ }^{1}$
}

\begin{abstract}
Dramatic changes in ecosystem services have motivated recent work characterizing their interactions, including identifying trade-offs and synergies. Although time is arguably implicit in these ideas of trade-offs and synergies (e.g., temporal dynamics or changes in ecosystem services), such interactions are routinely inferred based on the spatial relationships among ecosystem services alone (e.g., spatial concordance of ecosystem services indicates synergies, whereas incongruence signifies trade-offs). The limitations of this approach have not been fully explored. We quantified ecosystem service interactions using correlations among contemporary ecosystem services and compared these results to those derived by incorporating change in ecosystem services from an earlier decade. To document change over $\sim 60$ years in an urbanizing floodplain, we used aerial photography to map multiple floodplain-associated ecosystem services. Our results demonstrate how incorporating landscape baselines can influence measured synergies and trade-offs. Spatial correlations among contemporary ecosystem services missed several interactions that were detected when using prior baseline ecosystem services. Ignoring the history of ecosystem services and their change over time may result in missed opportunities to foster their synergies and lead to unnecessary trade-offs. Efforts to incorporate ecosystem services into land management should include long-term monitoring and baseline reconstructions of ecosystem services.
\end{abstract}

Key Words: ecosystem service mapping; landscape baseline; river floodplain; synergy; trade-off

\section{INTRODUCTION}

People rely on a wide range of ecosystem services (ES) from landscapes and ecosystems. Ensuring landscapes provide multiple benefits to diverse user groups is an ongoing challenge, especially because ES are interrelated and can interact in complex and unexpected ways (Bennett et al. 2009). When ES respond to shared drivers, such as land conversion or restoration, changes in one ES can impact other ES directly or indirectly, commonly known as an ES interaction (Bennett et al. 2009). Two routinely characterized interactions are trade-offs and synergies (Fig. 1). A trade-off occurs when an increase in one ES either directly or indirectly leads to a decline in another ES, such as crop production reducing fish habitat or having an impact on water quality. A synergy occurs when enhancing one ES increases another ES simultaneously. Riparian restoration for fish habitat that enhances scenic vistas for recreational paddlers is one example of a synergy.

To avoid problems and conflicts resulting from ES interactions, governments and managers throughout the world are increasingly adopting an ES perspective. For example, the Intergovernmental Panel for Biodiversity and Ecosystem Services was established to assess global biodiversity and ES in 2012, and the European Union aims to halt ES and biodiversity loss by 2020 (EC 2011). Compliance with the United States National Environmental Policy Act now requires ES monitoring, and land managers are currently developing guidelines for such efforts (Bear 2014). Despite increased integration of ES into policy and decision making, ES monitoring standards are still evolving. Although monitoring individual ES is challenging, monitoring multiple ES and their interactions is particularly difficult, in part because of major conceptual and methods gaps (Mouchet et al. 2014).

Understanding ES interactions at different temporal scales, both short-term and long-term, is another key challenge (Mouchet et al. 2014, Birkhofer et al. 2015). Ecosystem service interactions may involve time lags whereby historical decisions influence current provisioning of ES (Dallimer et al. 2015). A landscape baseline can be used as a reference point against which current landscape ES can be measured and compared, but rarely have baselines been used to understand the context of ES interactions (but see Haines-Young et al. 2012, Renard et al. 2015). Ecosystem baselines have been used in landscape ecology to better understand changes in ecosystems over time and under different scenarios (Bull et al. 2014). Such approaches may also be useful for understanding ES interactions.

Fig. 1. Hypothesized interactions among floodplain ecosystem services. Different drivers can lead to interactions such as tradeoffs and synergies among ecosystem services. Adapted from Bennett et al. 2009.

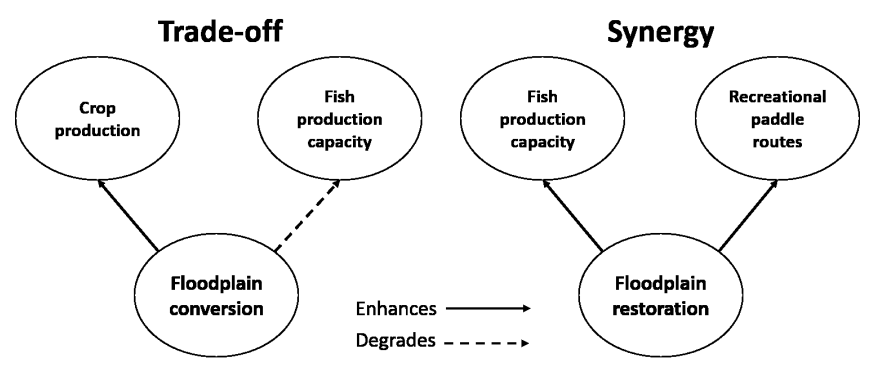

\section{.} .

\footnotetext{
${ }^{1}$ Department of Forest and Conservation Sciences, Faculty of Forestry, University of British Columbia
} 
More progress has been made assessing ES over space using maps to infer ES interactions (Raudsepp-Hearne et al. 2010, Qiu and Turner 2013). Typically, multiple ES are identified across broad regions and any spatial overlap (or lack thereof) is assumed to signify a particular type of ES interaction. The spatial overlap is often quantified using correlation coefficients and then positively correlated ES are assumed to be synergistic whereas negatively correlated ES are presumed to be trade-offs (Lautenbach et al. 2010, Raudsepp-Hearne et al. 2010). This approach is loosely analogous to a space-for-time substitution in that spatial relationships are used to infer dynamics over time. Widely used in ecology when long-term records are unavailable, space-for-time substitution is based on the assumption that temporal and spatial variability are equal (Pickett 1989). Unfortunately, inferring trade-offs and synergies using broad-scale spatial correlations among ES ignores several fundamental assumptions of a spacefor-time approach, including assumptions that landscape history is unimportant and that drivers of change are the same across large areas. Recent studies have shown that landscape history plays a critical role in modern ES (Dallimer et al. 2015), and interactions change over time (Renard et al. 2015). Furthermore, across a large study area, drivers of ES change are often heterogeneous.

Exploring ES over time presents a number of unique challenges. Distinguishing between ES capacity, flows, demand, and preferences is critical for understanding their temporal dynamics (Burkhard et al. 2009, 2012, Villamagna et al. 2013, Mouchet et al. 2014, Beier et al. 2015). Conceptually, flows refer to ES that actually reach people, whereas the capacity of ecosystems providing such flows is a distinct entity (Burkhard et al. 2014). Furthermore, although preferences for certain ES may change over time (Bürgi et al. 2015), a change in preference may not affect the capacity of a location to provide ES. In addition to ES capacity, the stocks of ecosystems that provide ES have also been termed potential ES supply, natural capital, etc. (Kienast et al. 2009, Burkhard et al. 2012); we also refer to stocks as ES capacity (Villamagna et al. 2013). Our indicators for ES are capacity-based indicators (Fig. 2; Haines-Young and Potschin 2010, Mouchet et al. 2014).

Fig. 2. Conceptual diagrams distinguishing different components to ecosystem services. For this study, we focus on interactions among capacity-based indicators of ecosystem services.

\begin{tabular}{|c|c|c|}
\hline \multirow{2}{*}{$\begin{array}{c}\text { Ecosystem } \\
\text { Service Capacity } \\
\text { (potential supply, natural } \\
\text { capital, stocks, beneficial } \\
\text { ecosystem processes, } \\
\text { ecosystem service providers) }\end{array}$} & $\begin{array}{c}\text { Ecosystem Service } \\
\text { Flows }\end{array}$ & $\begin{array}{c}\text { Ecosystem } \\
\text { Service Demand } \\
\text { (beneficiaries, human } \\
\text { populations, user groups, } \\
\text { values) }\end{array}$ \\
\hline
\end{tabular}

We incorporate long-term temporal changes in ES to showcase a rare, but fundamentally important approach for understanding ES interactions (Mouchet et al. 2014). We create maps of ES change ( $\triangle \mathrm{ES}$ ) from 1949 to 2006 . Using these $\Delta \mathrm{ES}$ maps, we correlate pairs of $\triangle E S$ across a river-floodplain landscape allowing identification of concomitant changes in ES, i.e., trade- offs or synergies. We contrast a $\Delta \mathrm{ES}$ change-over-time approach to the standard space-for-time approach, using static correlations to infer ES interactions. We expect inferences from these two approaches to disagree in several ways, with important consequences for understanding and characterizing ES interactions.

\section{Trade-offs or synergies may go undetected}

Space-for-time approaches may miss the ES trade-offs more easily detected by change-over-time approaches (Fig. 3, panel A). Tradeoffs may be missed when ES co-occur locally yet compete for space, such as with different crops that require similar fertile floodplain soils. Such crop types might appear to co-occur in space, i.e., a synergy, yet actually compete for space. When viewed over time, increases in one crop would lead to decreases in the other crop, hence, a trade-off. Such undetected trade-offs are also likely when ES data are aggregated by geographical or political units, e.g., watersheds or counties, as is common in ES mapping (Raudsepp-Hearne et al. 2010).

Fig. 3. Boxes represent scatter plots showing the relationship between two ecosystem services. Positively correlated ecosystem services are considered synergies, negatively correlated ecosystem services are trade-offs, and uncorrelated ecosystem services do not interact. S-Synergy, T-Trade-off, N-No interactions. Comparing space-for-time and change-over-time approaches, a trade-off can be missed when the space-for-time approaches show no interaction or a synergy, but the changeover-time approach shows a trade-off (Panel A). Synergies missed occur when space-for-time approaches show either a trade-off or no interaction, but the change-over-time approach shows a synergy (Panel B). Interactions detected where none occur are examples of when space-for-time approaches show a synergy or a trade-off, but change-over-time show no interaction (Panel C).

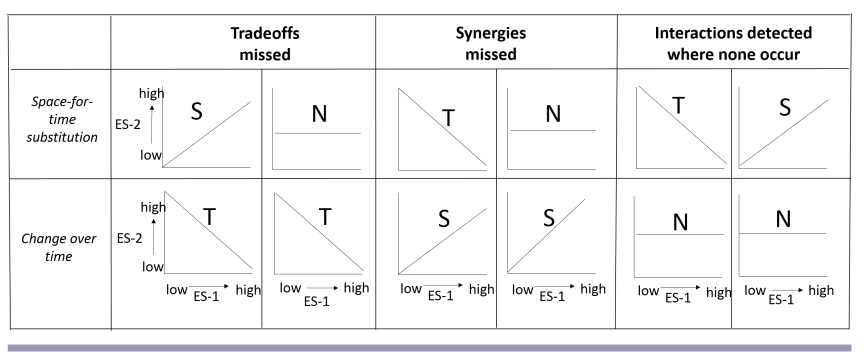

Similarly, a long-term synergy might not be evident using a spacefor-time approach (Fig. 3, panel B). When ES rely on some common landscape features or attributes, yet are spatially disparate, such ES may appear to trade-off across space but appear synergistic over time. For example, recreational activities and wildlife habitat may both be linked to forest cover attributes, yet not occur in the same specific locations because of other landscape characteristics, such as accessibility. Accessibility may increase recreation, while reducing the quality of wildlife habitat (a trade-off), yet both ES may respond positively to increases in forest cover (a synergy). Characterizations across space vs. over time may lead to a different understanding of the relationship between these ES. Ecosystem services maps created at a single 
Fig. 4. Approach for comparing spatial correlations of two different ecosystem services (ES) at one year with change-over-time approaches $(\triangle \mathrm{ES})$. We correlate the spatial distributions of ecosystem services at the reach level and compare these results to those correlating map differences in ecosystem services from 1949 to 2006 $(\Delta \mathrm{ES})$.
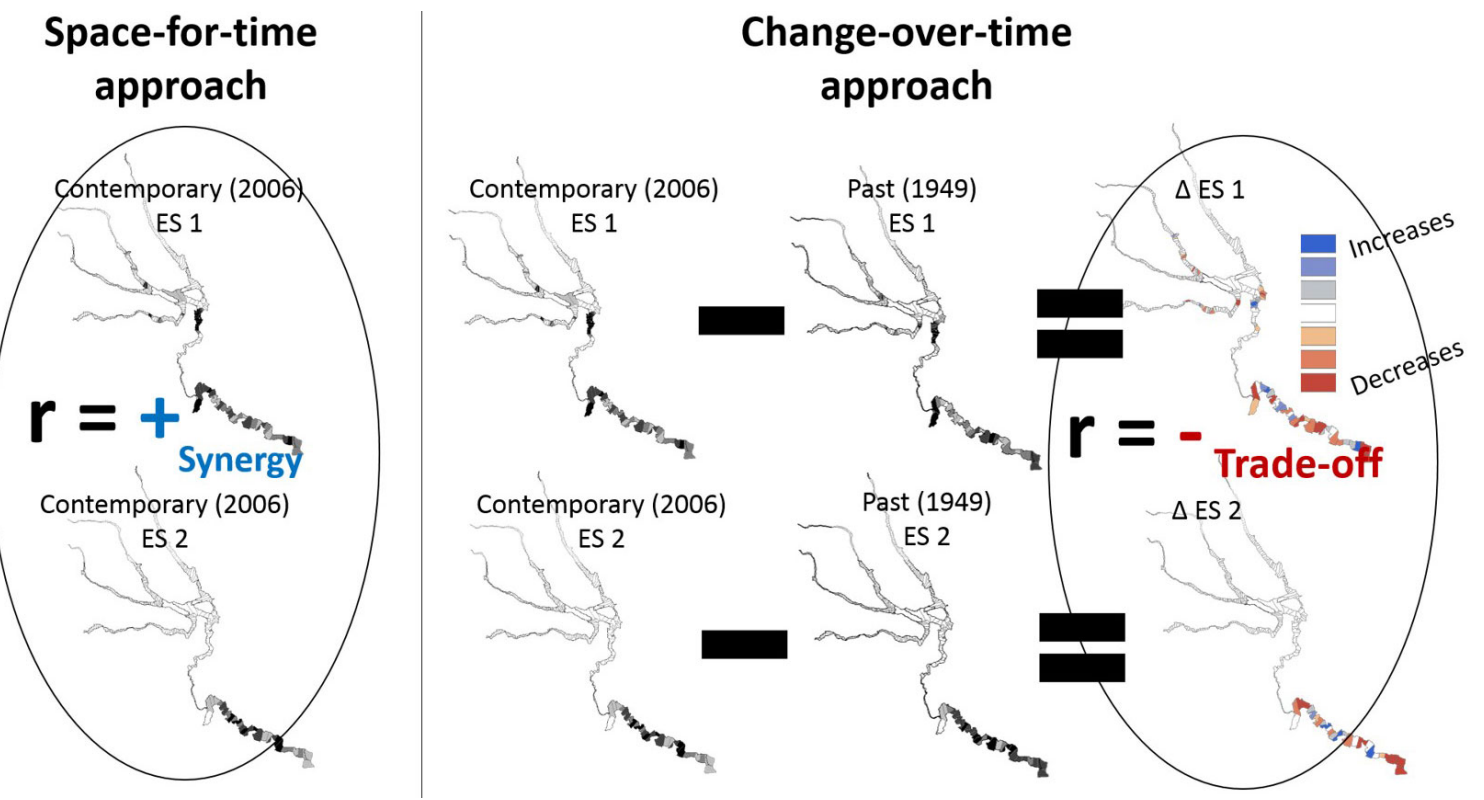

timeframe may suggest a trade-off, but when viewed over time, a synergy is evident because of the importance of shared attributes. Other potential outcomes include detection of an interaction when none occurs over time (Fig. 3, panel C).

Our goal is to determine if ES interactions determined from a map difference, i.e., change-over-time, approach provide additional insights to a spatial, i.e., space-for-time, approach. We explore multiple ES, including fish production, orchard production, forage production, recreation, and carbon storage. We ask one primary question: Does examining ES change-overtime $(\Delta \mathrm{ES})$ yield a different understanding of ES interactions than a space-for-time approach? We explore this question by comparing the significance and direction of correlations among pairs of ES mapped at one time frame to correlations incorporating prior historical ES and their change over time $(\Delta \mathrm{ES})$ using historical and contemporary aerial photography (Fig. 4). We explore ES interactions in a tributary river floodplain system to the Columbia River, the Wenatchee system floodplain.

\section{METHODS}

\section{Study site}

The Columbia River Basin (CRB) is among the world's most managed and regulated river basins, which has resulted in a number of unintended ES interactions. We focus on one of the Columbia River's tributary river floodplain systems, the Wenatchee system floodplain. The $210 \mathrm{~km}^{2}$ Wenatchee floodplain system is comprised of the Chiwawa River, White River, Little Wenatchee River, Nason Creek, and the Wenatchee mainstem floodplains (Fig. 5). Draining the eastern side of the Cascade Mountains, the watershed's heterogeneous soils, vegetation, and
Fig. 5. The Wenatchee system floodplain situated in central Washington State.

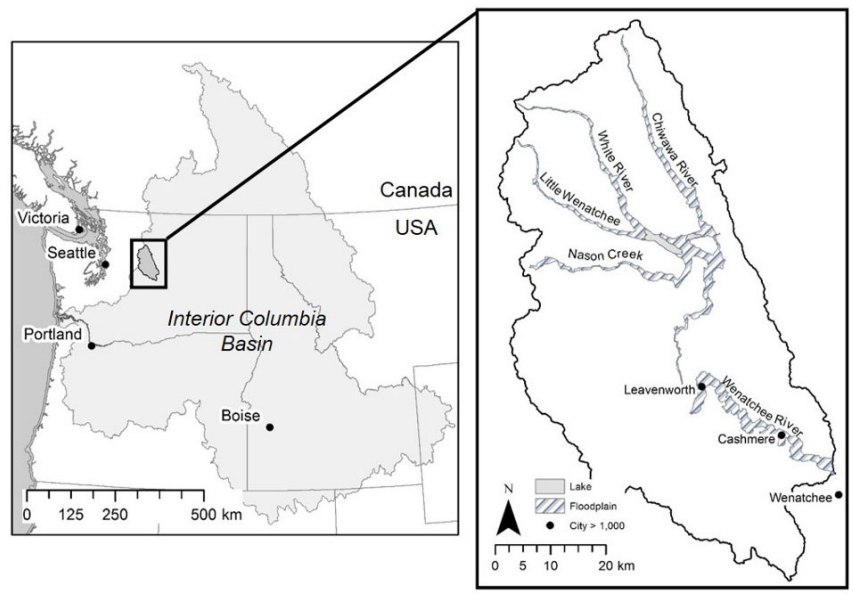

west to east precipitation gradient make this floodplain ideal for studying variability in ES interactions. The watershed's diverse user groups and ecosystems make understanding its ES interactions critical. This river floodplain has been rapidly becoming urbanized since the mid-20th century and has been modified by development since the late 1800's (Tomscha and Gergel 2015). The Wenatchee mainstem floodplain has been primarily converted to orchard agriculture and urban development, whereas its tributary floodplains are primarily forested and traversed by road networks. The Wenatchee system 
floodplain is a popular destination for recreation and agritourism. Urbanization and forest densification have been the main drivers of change in the Wenatchee region during this time period (Fig. 6; Tomlinson et al. 2011, Hagmann et al. 2014).

Fig. 6. Primary drivers of change in the Wenatchee system floodplain and their impacts to ecosystem services. Our approach links land cover, river-floodplain characteristics, and other spatial data to map ecosystem services. Changes in landscape attributes resulting from forest densification and urbanization played an important role in driving ecosystem service interactions. Ecosystem services are likely to interact through their shared links to land cover.

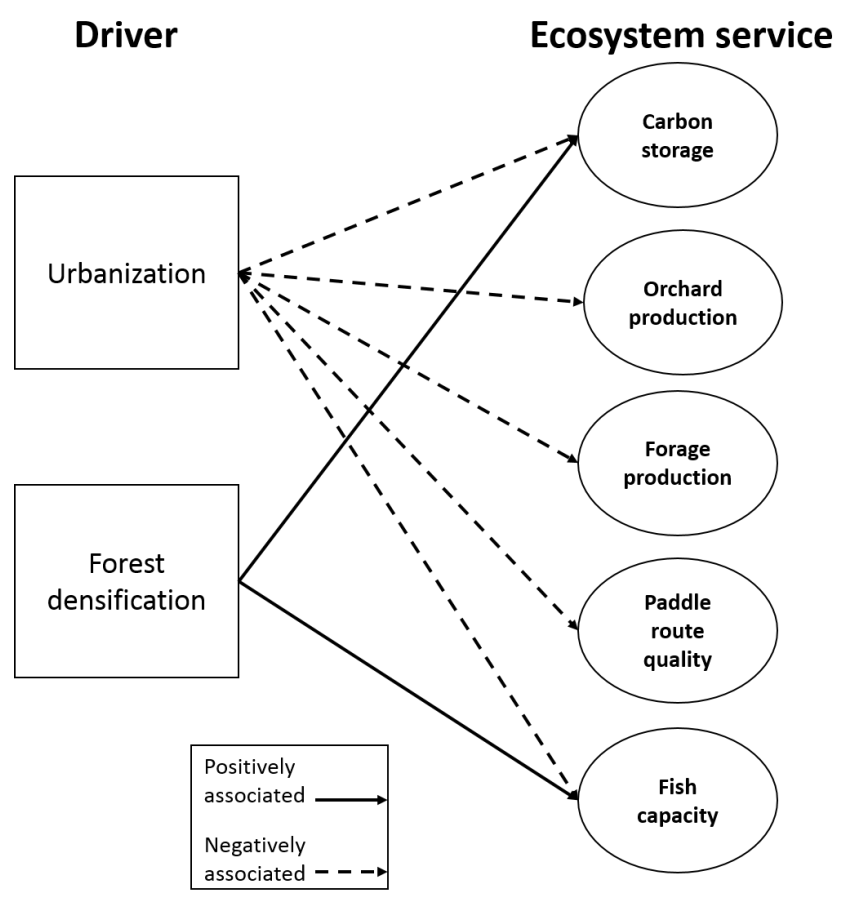

\section{Mapping ecosystem services (ES) capacity}

To create maps of ES capacity at distinct time periods, rather than an amalgamation of time frames as common ES research (Holland et al. 2011), ES capacity was primarily derived from land cover maps and detailed floodplain characteristics based on contemporary (2006) and historical (1949) aerial photography (Tomlinson et al. 2011). Aerial photography from September 1949 was obtained from the National Archives and Records Administration (http://www.archives.gov), and contemporary (July 2006) aerial photography was gathered from the USDA National Agricultural Imagery Program (USDA 2006, Tomlinson et al. 2011). Land-cover classes were manually interpreted at a 1:4000 scale from high-resolution $(1 \mathrm{~m})$ aerial photography and were combined with other geospatial data to quantify ES capacity. Our high-resolution photography allowed for identification of 12 different land-cover classes (urban, orchards, fields, shrub, dense conifer forest, moderately dense conifer forest, low density conifer forest, high density mixed conifer/broadleaf forest, moderately dense mixed conifer/broadleaf forest, low density mixed conifer broadleaf forest, water, and rock/snow). Land-cover and ES capacity were mapped only within the Wenatchee floodplain. The floodplain was digitized using a hillshade derivative of USGS 10 $\mathrm{m}$ DEM and 1:24,000 topoquads (Tomlinson et al. 2011). See Tomlinson et al. 2011 for further details on aerial photography acquisition and orthorectification.

We mapped capacity of the floodplain to provide five ES (orchard production, forage production, carbon storage, paddle route quality, and fish capacity) in both 1949 and 2006, summarizing ES capacity at the river-reach scale. River reaches were digitized as river segments 10-20 times the local stream length $(n=424)$. Tomlinson et al. digitized starting at the mouth of the Wenatchee mainstem moving upstream with an emphasis on keeping reach size relatively consistent with surrounding reaches (Tomlinson et al. 2011). The average area of a river reach was 50 ha, and the average river length of a reach was $675 \mathrm{~m}$ in 2006 and $689 \mathrm{~m}$ in 1949.

We incorporated multiple landscape characteristics to estimate important locations for the capacity of ES over time (Table 1). Because different indicators can lead to different outcomes for ES evaluations (Liss et al. 2013), we focused on combining biophysical attributes into comparable production functions applicable in both sets of high-resolution air photos, which also helped to maintain consistency among any service measured over time (Table 1). Capacity for "orchard" and "forage production" were mapped on an areal basis and normalized based on their relative area per reach. Carbon storage was estimated based on local forest inventory analysis (FIA) data plots and the online tool carbon online estimator (COLE), as well as carbon storage values for different land-cover types derived from literature reviews (Nowak and Crane 2002, Penman et al. 2003, Ruesch and Gibbs 2008, O'Connell et al. 2014, Van Deusen and Heath 2014; Table 2). We linked land-cover types to carbon-storage values and summarized total carbon storage at the reach scale (Table 1).

Paddle route quality for each reach was measured based on the presence or absence of currently documented paddle routes (http://www.americanwhitewater.org/content/River/state-summary/ state/WA/ 2014) combined with land cover bordering the paddle route in the two time periods. Paddle routes were common in all but the most inaccessible upper reaches. We used the same paddle routes in 1949 and 2006 because accessibility to paddle routes did not change from 1949 to 2006 (an assumption confirmed by road maps at each time frame). We are not aware of any data to determine how important recreational paddling was on this river in 1949, but acknowledge that demand is also dynamic. Although preferences for land cover varies with different user groups (Gómez-Limón and de Lucío Fernández 1999), natural land cover is often preferred to urban cover and agricultural land (Ulrich 1986). Traditional agriculture lands are also aesthetically pleasing (Bergstrom et al. 1985, Brady 2006). Thus from an aesthetics perspective, we assumed forest cover was considered the best for paddling, followed by agricultural and urban land cover. River length was also important because paddlers would spend a greater amount of time in reaches with longer lengths (Table 1).

Fish capacity was based on a suite of important ecological characteristics, particularly relevant to salmonid habitat: features such as wetlands, dry channels, and slow and stagnant channels, 
Table 1. Production functions used to map the capacity of each river reach to provide ecosystem services.

\begin{tabular}{ll}
\hline \hline Ecosystem service & Production function \\
\hline Carbon storage $^{\dagger}$ & $=\left(\right.$ Area ${ }_{\text {land cover } 1} \times$ Mean above-ground carbon storage $\left.{ }_{\text {land cover }}+\ldots\right) /$ Reach area \\
Orchard production & $=$ Orchard area/Reach area \\
Forage production & $=$ Field area/Reach area \\
Paddle route quality & $=$ Paddle route $\times[\%$ Natural cover $+0.5(\%$ Agriculture $)] \times$ Channel length \\
& where Paddle route $=1$ if a paddle route is present or paddle route $=0$ if a paddle route is not present \\
Fish capacity & $=$ Normalized wetland importance + Normalized slow and stagnant channel importance + Normalized dry channel importance \\
& + Normalized wood importance \\
& where Wood importance index $=[\%$ Conifer $+0.75(\%$ Mixed conifer broadleaf $)] \times$ Sinuosity
\end{tabular}

See Table 2 for mean above-ground carbon storage for different land-cover types

Table 2. Above-ground carbon storage for different land-cover types.



which were digitized from high-resolution air photos. The area of each habitat was normalized by reach area and scaled from 0-1. We then created a wood importance index to account for large wood's importance for habitat formation. We determined the capacity of each forest type to provide large wood based on land cover within $75 \mathrm{~m}$, the minimum buffer width for surface waters in eastern Washington State (State of Washington, Department of Ecology 2013). Coniferous trees are more decay resistant, and thus riparian coniferous forests were considered more important for habitat formation than mixed coniferous broadleaf forests (Hyatt and Naiman 2001, Hart et al. 2013). Furthermore, the sinuosity of the river in each reach was also considered in our wood importance index, in which reaches with higher sinuosity or curvature were considered better for fish. We normalized this index from 0-1 (Table 1). All ES were aggregated at the scale of a river reach, because aggregating ES is a typical approach for mapping ES. All ES were normalized by reach area to account for differing reach sizes.

\section{Ecosystem services interaction analyses}

Through the above production functions and as a result of drivers across the Wentchee floodplain, we expected ecosystem services to interact (Fig. 6). To identify these interactions, we mimicked the general approaches of research quantifying ES interactions (e.g., Raudsepp-Hearne et al. 2010, Wu et al. 2013, Turner et al. 2014) by determining correlations between pairs of ES in each river reach segment. Then, we compared the direction and strength of correlations calculated using a static approach as in Raudsepp-Hearne et al. (2010) with correlations calculated using map differences from 1949 and 2006 ( $\Delta \mathrm{ES}$; Fig. 4). We refer to these contrasting analyses as the space-for-time approach and change-over-time approach $(\Delta \mathrm{ES})$, respectively. The space-fortime approach was conducted twice, once in 1949 and once in 2006. Because of non-normality of ES capacity distributions, we used Spearman's rank correlations, a standard approach for evaluating ES interactions (R Core Team 2014, Raudsepp-Hearne et al. 2010). Negatively correlated ES $(p<0.05)$ were considered trade-offs, whereas positively correlated ES were considered synergistic. Nonsignificant correlation coefficients indicated noninteracting ES.

\section{RESULTS}

High agreement between space-for-time approaches at different time frames

A space-for-time approach, used to separately analyze ES in 1949 and then also in 2006, characterized ES interactions similarly (Table 3, Fig. 7). Trade-offs among orchards/carbon, orchards/ fish capacity, forage/carbon storage, and carbon storage/paddle routes were detected in 1949 and in 2006. In 1949, one additional trade-off was detected between forage/fish capacity. Synergies detected in both years were orchard/forage, orchard/paddle routes, and forage/paddle routes. An additional synergy, carbon storage/fish capacity, was detected in 1949.

\section{Little agreement between space-for-time and change-over-time approaches}

Space-for-time and change-over-time approaches rarely agreed in their characterizations of ES interactions. Different approaches consistently differed in their characterization of all trade-offs, detecting trade-offs among different ES pairs (Fig. 7). The spacefor-time approach and change-over-time approach detected different numbers of trade-offs (Table 3). The space-for-time approach identified more trade-offs (five in 1949 and four in 2006) than the change-over-time approach (two for $\Delta \mathrm{ES}$; Table 3). For all possible pairwise interactions, space-for-time results agreed 
Table 3. Types of interactions identified using two mapping methods: space-for-time substitution (at both 1949 and 2006) and changeover-time $(\Delta \mathrm{ES})$. Pairwise Spearman's rank correlation result. T-Trade-off, $\mathrm{S}$ - Synergy, N-No interaction. *Significant at 0.05 .

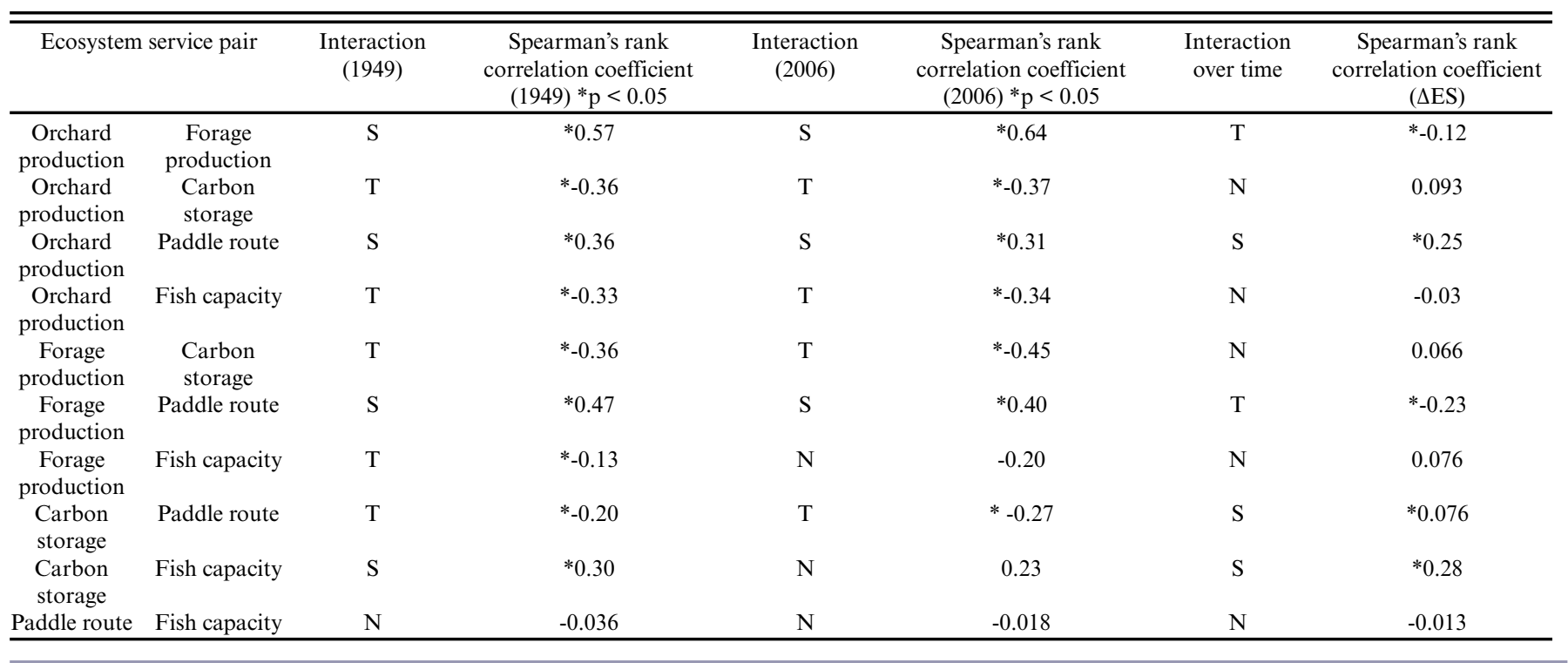

with change-over-time results in two instances for 2006 and three instances in 1949. Space-for-time approaches and the change-overtime approach both identified a synergistic relationship between orchard production and paddle routes and also characterized a lack of interaction between forage production and fish capacity (Table 3). Change-over-time and space-for-time approaches in 1949 also both identified a synergy between carbon storage and fish capacity.

Fig. 7. Interaction diagrams for five ecosystem services. Correlations between ecosystem services were determined using two different approaches: space-for-time substitution (left) and change-over-time (right). Circles represent different ecosystem services. Significant Spearman's rank correlation coefficients $(\mathrm{p}<$ $0.05)$ are represented with different colored lines. Blue lines indicate ecosystem service synergies, red lines trade-offs. Ecosystem services not connected by lines were not significantly correlated. Line width is scaled based on strength of correlation.

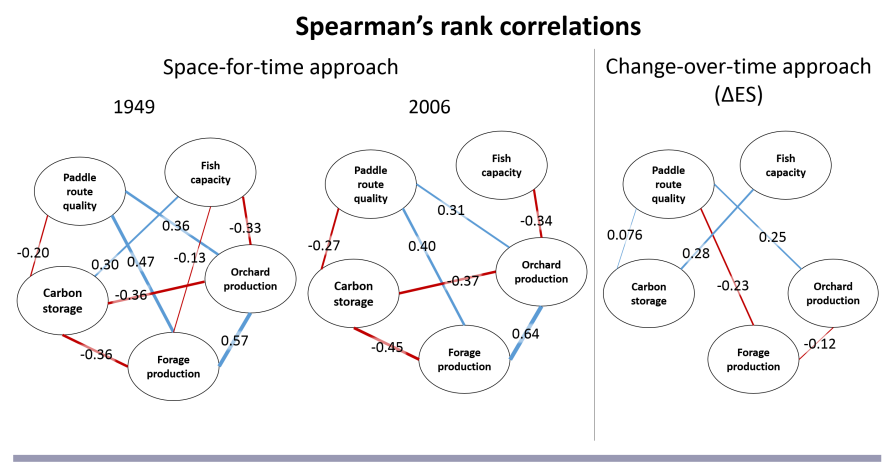

Two trade-offs with forage production, demonstrated using the change-over-time approach, were deemed synergies using the spacefor-time approach (forage/orchard production and forage/paddle routes). Furthermore, the change-over-time approach found a synergy among carbon storage/paddle routes whereas the spacefor-time approach (2006) deemed this interaction a trade-off. The space-for-time approach (2006) detected three ES trade-offs (orchard production/carbon storage, orchard production/fish capacity, and forage production/carbon storage) whereas no interactions occurred according to the change-over-time approach (Table 3). Additionally, space-for-time approaches in 1949 identified a trade-off between forage production and fish capacity that was not detected in 2006 and not detected over time.

\section{DISCUSSION}

Our results demonstrate that analyses using space-for-time vs. change-over-time approaches can yield different results, and thus, very different characterizations of ES interactions. Importantly, these approaches differed most in their characterizations of tradeoffs as the two approaches always identified different pairwise trade-offs. Furthermore, the space-for-time approach (2006) identified fewer synergies than the change-over-time approach. We discuss the three main issues facing ES interactions research: (1) how violating or ignoring the basic assumptions of a space-fortime approach may lead to misunderstandings of ES interactions; (2) how the temporal change in landscape drivers plays a key role in shaping ES interactions; and (3) how data structure influences detection of ES interactions. For results that differed for space-fortime vs. change-over-time approaches, we summarized and explained our findings in detail in light of these three major themes (Table 4). We conclude by exploring how long-term approaches may help us better understand ES bundles on dynamic landscapes and reflect on potential implications for management.

Landscape heterogeneity means a space-for-time approach can misconstrue ecosystem service interactions

Despite widely acknowledged limitations and assumptions of space-for-time substitutions, such assumptions and their implications are rarely explicitly addressed in ES research. Spacefor-time substitution is a common approach in ecological research 
Table 4. Primary issues resulting in differing results in space-for-time vs. change-over-time approaches for identifying ecosystem service interactions.

\begin{tabular}{|c|c|c|c|c|c|}
\hline \multirow{2}{*}{$\begin{array}{l}\text { Why interactions differed using } \\
\text { space-for-time vs. change-over- } \\
\text { time approaches }\end{array}$} & \multicolumn{2}{|c|}{ Ecosystem service pair } & \multicolumn{2}{|c|}{$\begin{array}{l}\text { Interaction detected using } \\
\text { contrasting approaches }\end{array}$} & \multirow[t]{2}{*}{ Detailed explanation } \\
\hline & & & $\begin{array}{l}\text { Space-for- } \\
\text { time (2006) }\end{array}$ & $\begin{array}{l}\text { Change- } \\
\text { over-time } \\
\quad(\Delta)\end{array}$ & \\
\hline \multirow{2}{*}{$\begin{array}{l}\text { Landscape heterogeneity } \\
\text { means a space-for-time } \\
\text { approach can misconstrue ES } \\
\text { interactions }\end{array}$} & $\begin{array}{l}\text { Carbon } \\
\text { storage }\end{array}$ & $\begin{array}{l}\text { Paddle route } \\
\text { quality }\end{array}$ & $\mathrm{T}$ & $\mathrm{S}$ & $\begin{array}{l}\text { Tend to occur in different spatial locations, but are linked } \\
\text { through increases in forest cover }\end{array}$ \\
\hline & $\begin{array}{l}\text { Carbon } \\
\text { storage }\end{array}$ & Fish capacity & $\mathrm{N}$ & $\mathrm{S}$ & $\begin{array}{l}\text { Spatial distributions not tightly linked, but both improved with } \\
\text { increases in forest cover }\end{array}$ \\
\hline \multirow[t]{4}{*}{$\begin{array}{l}\text { Deeper baselines may be } \\
\text { needed }\end{array}$} & $\begin{array}{l}\text { Orchard } \\
\text { production }\end{array}$ & $\begin{array}{l}\text { Carbon } \\
\text { storage }\end{array}$ & $\mathrm{T}$ & $\mathrm{N}$ & $\begin{array}{l}\text { Land clearing and wetland draining for forage and orchard } \\
\text { production occurred prior to } 1949 \text {, thus the potential interactions } \\
\text { among these crops and fish capacity and carbon storage were not } \\
\text { detected from } 1949 \text { to } 2006\end{array}$ \\
\hline & $\begin{array}{l}\text { Orchard } \\
\text { production }\end{array}$ & Fish capacity & $\mathrm{T}$ & $\mathrm{N}$ & \\
\hline & $\begin{array}{l}\text { Forage } \\
\text { production }\end{array}$ & $\begin{array}{l}\text { Carbon } \\
\text { storage }\end{array}$ & $\mathrm{T}$ & $\mathrm{N}$ & \\
\hline & $\begin{array}{l}\text { Forage } \\
\text { production }\end{array}$ & Fish capacity & $\mathrm{T}$ & $\mathrm{N}$ & \\
\hline \multirow[t]{2}{*}{$\begin{array}{l}\text { Data structure matters: data } \\
\text { aggregation can obscure trade- } \\
\text { offs }\end{array}$} & $\begin{array}{l}\text { Orchard } \\
\text { production }\end{array}$ & $\begin{array}{c}\text { Forage } \\
\text { production }\end{array}$ & $\mathrm{S}$ & $\mathrm{T}$ & $\begin{array}{l}\text { These crops occur in the same reaches, but compete for space in } \\
\text { this floodplain, which was already nearly completely converted } \\
\text { for agriculture in } 1949\end{array}$ \\
\hline & $\begin{array}{c}\text { Forage } \\
\text { production }\end{array}$ & $\begin{array}{c}\text { Paddle route } \\
\text { quality }\end{array}$ & $\mathrm{S}$ & $\mathrm{T}$ & $\begin{array}{l}\text { These ecosystem services occur in spatially similar locations, but } \\
\text { loss of forage production for natural covers leads to } \\
\text { improvements in paddle route quality }\end{array}$ \\
\hline
\end{tabular}

when temporal records are unavailable and one assumes that spatial and temporal variability are comparable. Thus, this approach is considered most robust in locations in which landscape history is unimportant and drivers remain consistent throughout the landscape (Pickett 1989). Such assumptions are unlikely to hold across the extent of regional ES mapping studies when landscape heterogeneity is high.

Spatial variability (or landscape heterogeneity) has several implications in this context. In areas with underlying heterogeneity, i.e., variable terrain, soil fertility, precipitation, the original historical spatial distributions of ES were also likely nonuniform, presenting two potential problems for interpretation of space-fortime results. First, implicitly assuming all locations were originally homogenous, and thus originally of equal suitability for ES production, as presumed by space-for-time (e.g., RaudseppHearne et al. 2010) is very unlikely. As a result, when space-fortime results are used to infer ES interactions, low levels of ES in contemporary landscapes may be presumed to be the result of prior declines, and hence, the result of a trade-off. Many ES likely occurred in different locations historically because of underlying patterns of landscape heterogeneity; thus, an erroneous trade-off may be detected using space-for-time approaches.

Another fundamental assumption of the space-for-time approach is that drivers are the same throughout the study area (Pickett 1989), yet ES interaction research often does not account for spatial variability in drivers. For example, agricultural conversion will be influenced by differing crop type requirements for soil, terrain, or moisture. As a result, certain crop types will rarely be colocated (Baudry and Thenail 2004) and interact little over time, yet be perceived as making trade-offs across a contemporary landscape when viewed at one time. Drivers of ES change often and vary across study areas.

\section{Deeper baselines may be needed to capture some drivers}

Because dominant drivers can change over time, more than one baseline may be informative. Our $\sim 60$-year timeframe is one of the longest reconstructions of multiple ES interactions to date, yet our change-over-time results, which do not detect certain interactions commonly found using static ES maps, may reflect the absence of specific drivers of change over our study period. For example, crop production has been negatively correlated with water quality (Qiu and Turner 2013), carbon, nature appreciation, soil organic carbon (Turner et al. 2014), and habitat conservation (Wu et al. 2013). We found a trade-off between carbon storage and both forage and orchards using a space-for-time approach, but not using a change-over-time approach, which showed no interaction. This discrepancy likely reflects the fact that agricultural land conversion was largely complete prior to 1949. Similar dynamics might be apparent with wetland losses and reductions of fish capacity because most wetlands were already lost by 1949 (Tomlinson et al. 2011). Selecting an appropriate baseline landscape is key to capturing land-cover conversions that drive ES interactions, whereas capturing initial losses in ES due to frontier clearing requires even longer time frames.

Data structure matters: data aggregation can obscure trade-offs Different ways of data aggregation influence characterizations of interactions (Anderson et al. 2009, Felipe-Lucia et al. 2014). Typically, total amounts of ES are spatially aggregated into watersheds, counties, grids, pixels, etc., prior to analysis of 
cumulative or summary values, e.g., percent orchard, total carbon storage, etc. (Raudsepp-Hearne et al. 2010, Wu et al. 2013, Turner et al. 2014). Such aggregated information obscures interactions when ES compete for space. For example, different crop types competing for productive floodplain soils will be seen as spatially concurrent in aggregated datasets, thereby showing a synergistic relationship. In the study site examined, orchard and forage production appear synergistic using space-for-time substitution, but temporally, these ES competed for space, i.e., a clear tradeoff. Two trade-offs were likely misidentified as synergies using the space-for-time approach with aggregation at the reach scale: orchards/forage and paddle routes/forage production. Incorporating historical data and determining correlations in $\triangle \mathrm{ES}$ may moderate these issues because correlating mapped $\Delta \mathrm{ES}$ shows temporal relationships in addition to spatial relationships.

\section{IMPLICATIONS AND CONCLUSIONS}

\section{Long-term ecosystem service bundles and interactions with landscape change}

Globally, land-use change often follows typical transitions from natural ecosystems to frontier expansion followed by agricultural and urban development (Foley et al. 2005). The suite (or bundles) of ES produced by a landscape throughout these different phases also differs (Foley et al. 2005). Because ES interactions change through time (Renard et al. 2015), capturing only a snapshot of ES interactions at different phases of these transitions may lead to contrasting characterizations of ES interactions, as our work demonstrated for the agricultural to urban development transition. Although a temporal approach is fundamental to understanding ES interactions, it can also add to our understanding of ES bundles, which to date has largely been spatial (Renard et al. 2015). Bundles (or sets of co-occurring ES) are often identified using cluster analysis on static maps (Raudsepp-Hearne et al. 2010). Temporal change in ES bundles has rarely been considered until recently (Renard et al. 2015). A space-for-time approach may be missing the dynamics of ES bundles, and key future work should address these dynamics. Multiple time steps may be needed to show how ES interactions and ES bundles change from pristine to highly modified landscapes.

\section{Implications for management}

Missed ES synergies are missed opportunities for demonstrating management success. Ecosystem service synergies present opportunities to enhance multiple ES simultaneously (Anderson et al. 2009, Raudsepp-Hearne et al. 2010, Qiu and Turner 2013). If land managers depend on space-for-time approaches for monitoring the success of ES restoration, successful synergies may remain undocumented. For instance, space-for-time approaches missed three important synergies among fish capacity, carbon storage, and paddle routes. Riparian restoration may simultaneously improve fish capacity, carbon storage, and paddle routes, but space-for-time approaches may miss opportunities to demonstrate such synergies. Demonstrating successful management for ES synergies requires a temporal approach.

Our work presents several important implications for the management of trade-offs. When ES trade-offs go undetected, and especially when they are mistaken for synergies, unintentional ES losses may occur. Space-for-time substitution missed two trade-offs involving forage production, instead identifying them as synergies with orchard production and paddle routes. Agricultural shifts, i.e., changes in crop types or agricultural intensification, may result in trade-offs that shape the character of a landscape, such as the occurring types and amount of agritourism (Gao et al. 2013). Incorporating baselines may be crucial for correctly characterizing ES trade-offs, especially when using aggregated ES data, which can obscure locally space competing ES. Furthermore, change-over-time approaches also likely missed several longer-term trade-offs; thus even longer baselines may be needed to determine the true dynamics among certain ES pairs as landscapes evolve.

The benefits of using historical information to characterize ES interactions are numerous. Space-for-time substitution may be inadequate and misleading for exploring ES interactions across heterogeneous landscapes affected by multiple drivers. As approaches for ES measurement and mapping evolve, acknowledging the value of baseline information in such assessments is key. The importance of long-term monitoring to adequately capture complex long-term ES interactions cannot be overstated; it can help us avoid or minimize trade-offs and adequately track synergies that simultaneously support multiple ES.

Responses to this article can be read online at: http://www.ecologyandsociety.org/issues/responses. $\mathrm{php} / 8345$

\section{Acknowledgments:}

This research was supported by the Faculty of Forestry, the Namkoong Family Fellowship in Forest Sciences, VanDusen Graduate Fellowship in Forestry, CANFOR Corporation Fellowship in Forest Ecosystem Management, Pacific Institute for Climate Solutions, and NSERC. Baseline data air photos were created by Matt Tomlinson. We thank Michelle Jackson for comments on an early draft. We also thank Nicholas Coops, Simon Donner, and Lori Daniels for input throughout the project.

\section{LITERATURE CITED}

American Whitewater. 2014. http://www.americanwhitewater. org/.

Anderson, B. J., P. R. Armsworth, F. Eigenbrod, C. D. Thomas, S. Gillings, A. Heinemeyer, D. B. Roy, and K. J. Gaston. 2009. Spatial covariance between biodiversity and other ecosystem service priorities. Journal of Applied Ecology 46(4):888-896. http:// dx.doi.org/10.1111/j.1365-2664.2009.01666.x

Baudry, J., and C. Thenail. 2004. Interaction between farming systems, riparian zones, and landscape patterns: a case study in western France. Landscape and Urban Planning 67:121-129. http://dx.doi.org/10.1016/S0169-2046(03)00033-1

Bear, D. 2014. Integration of ecosystem services valuation analysis into National Environmental Policy Act compliance: legal and policy perspectives. Pages 1-18 in L. Olander, editor. Federal resource management and ecosystem services guidebook. 
National Ecosystem Services Partnership, Duke University, Durham, North Carolina, USA.

Beier, C. M., J. Caputo, and P. M. Groffman. 2015. Measuring ecosystem capacity to provide regulating services: forest removal and recovery at Hubbard Brook (USA). Ecological Applications 25(7):2011-2021. http://dx.doi.org/10.1890/14-1376.1

Bennett, E. M., G. D. Peterson, and L. J. Gordon. 2009. Understanding relationships among multiple ecosystem services. Ecology Letters 12(12):1394-1404. http://dx.doi.org/10.1111/ j.1461-0248.2009.01387.x

Bergstrom, J. C., B. L. Dillman, and J. R. Stoll. 1985. Public environmental amenity benefits of private land: the case of prime agricultural land. Southern Journal of Agricultural Economics 17:139-149.

Birkhofer, K., E. Diehl, J. Andersson, J. Ekroos, A. Früh-Müller, F. Machnikowski, V. L. Mader, L. Nilsson, K. Sasaki, M. Rundlöf, V. Wolters, and H. G. Smith. 2015. Ecosystem services - current challenges and opportunities for ecological research. Frontiers in Ecology and Evolution 2:87. http://dx.doi.org/10.3389/fevo.2014.00087

Brady, E. 2006. The aesthetics of agricultural landscapes and the relationship between humans and nature. Ethics, Place, and Environment 9(1):1-19. http://dx.doi.org/10.1080/13668790500518024

Bull, J. W., A. Gordon, E. A. Law, K. B. Suttle, and E. J. MilnerGulland. 2014. Importance of baseline specification in evaluating conservation interventions and achieving no net loss of biodiversity. Conservation Biology 28(3):799-809. http://dx.doi. org/10.1111/cobi. 12243

Bürgi, M., J. Silbernagel, J. Wu, and F. Kienast. 2015. Linking ecosystem services with landscape history. Landscape Ecology 30:11-20. http://dx.doi.org/10.1007/s10980-014-0102-3

Burkhard, B., M. Kandziora, Y. Hou, and F. Müller. 2014. Ecosystem service potentials, flows and demands - concepts for spatial localisation, indication and quantification. Landscape Online 34:1-32. http://dx.doi.org/10.3097/LO.201434

Burkhard, B., F. Kroll, F. Müller, and W. Windhorst. 2009. Landscapes' capacities to provide ecosystem services - a concept for land-cover based assessments. Landscape Online 15:1-22. http://dx.doi.org/10.3097/LO.200915

Burkhard, B., F. Kroll, S. Nedkov, and F. Müller. 2012. Mapping ecosystem service supply, demand and budgets. Ecological Indicators 21:17-29. http://dx.doi.org/10.1016/j.ecolind.2011.06.019

Dallimer, M., Z. G. Davies, D. F. Diaz-porras, K. N. Irvine, L. Maltby, P. H. Warren, P. R. Armsworth, and K. J. Gaston. 2015. Historical influences on the current provision of multiple ecosystem services. Global Environmental Change 31:307-317. http://dx.doi.org/10.1016/j.gloenvcha.2015.01.015

European Commission (EC). 2011. Our life insurance, our natural capital: an EU biodiversity strategy to 2020. European Commission, Brussels, Belgium. [online] URL: http://ec.europa. eu/environment/nature/biodiversity/comm2006/pdf/

EP resolution april2012.pdf

Felipe-Lucia, M. R., F. A. Comin, and E. M. Bennett. 2014. Interactions among ecosystem services across land uses in a floodplain agroecosystem. Ecology and Society 19(1):20. http:// dx.doi.org/10.5751/es-06249-190120

Foley, J. A., R. DeFries, G. P. Asner, C. Barford, G. Bonan, S. R. Carpenter, F. S. Chapin, M. T. Coe, G. C. Daily, H. K. Gibbs, J. H. Helkowski, T. Holloway, E. A. Howard, C. J. Kucharik, C. Monfreda, J. A. Patz, I. C. Prentice, N. Ramankutty, and P. K. Snyder. 2005. Global consequences of land use. Science 309 (5734):570-574. http://dx.doi.org/10.1126/science.1111772

Gao, J., C. Barbieri, and C. Valdivia. 2013. Agricultural landscape preferences: implications for agritourism development. Journal of Travel Research 53(3):366-379. http://dx.doi.org/10.1177/00472$\underline{87513496471}$

Gómez-Limón, J., and J. V. de Lucío Fernández. 1999. Changes in use and landscape preferences on the agricultural-livestock landscapes of the central Iberian Peninsula (Madrid, Spain ). Landscape and Urban Planning 44:165-175. http://dx.doi. org/10.1016/S0169-2046(99)00020-1

Hagmann, R. K., J. F. Franklin, and K. N. Johnson. 2014. Historical conditions in mixed-conifer forests on the eastern slopes of the northern Oregon Cascade Range, USA. Forest Ecology and Management 330:158-170. http://dx.doi.org/10.1016/ j.foreco.2014.06.044

Haines-Young, R., and M. Potschin. 2010. The links between biodiversity, ecosystem services and human well-being. Pages 110-139 in D. G. Raffaelli and C. L. J. Frid, editors. Ecosystem ecology: a new synthesis. BES Ecological Reviews Series. Cambridge University Press, Cambridge, UK. http://dx.doi. org/10.1017/cbo9780511750458.007

Haines-Young, R., M. Potschin, and F. Kienast. 2012. Indicators of ecosystem service potential at European scales: mapping marginal changes and trade-offs. Ecological Indicators 21:39-53. http://dx.doi.org/10.1016/j.ecolind.2011.09.004

Hart, S. K., D. E. Hibbs, and S. S. Perakis. 2013. Riparian litter inputs to streams in the central Oregon Coast Range. Freshwater Science 32(1):343-358. http://dx.doi.org/10.1899/12-074.1

Holland, R. A., F. Eigenbrod, P. R. Armsworth, B. J. Anderson, C. D. Thomas, and K. J. Gaston. 2011. The influence of temporal variation on relationships between ecosystem services. Biodiversity and Conservation 20(14):3285-3294. http://dx.doi. org/10.1007/s10531-011-0113-1

Hyatt, T. L., and R. J. Naiman. 2001. The residence time of large woody debris in the Queets River, Washington, USA. Ecological Applications 11(1):191-202. http://dx.doi.org/10.1890/1051-0761 (2001)011[0191:trtolw]2.0.co:2

Kienast, F., J. Bolliger, M. Potschin, R. S. de Groot, P. H. Verburg, I. Heller, D. Wascher, and R. Haines-Young. 2009. Assessing landscape functions with broad-scale environmental data: insights gained from a prototype development for Europe. Environmental Management 44(6):1099-1120. http://dx.doi. org/10.1007/s00267-009-9384-7

Lautenbach, S., M. Volk, B. Gruber, C. F. Dormann, and R. Seppelt. 2010. Quantifying ecosystem service trade-offs. In D. A. Swayne, W. Yang, A. A. Voinov, A. Rizzoli, and T. Filatova, editors. International congress on environmental modelling and 
software modelling for environment's sake. Ottawa, Canada. [online] URL: http://www.biometrie.uni-freiburg.de/mitarbeiter/ dormann/lautenbach2010iemsconference-estradeoffs.pdf

Liss, K. N., M. G. E. Mitchell, G. K. Macdonald, S. L. Mahajan, J. Méthot, A. L. Jacob, D. Y. Maguire, G. S. Metson, C. Ziter, K. Dancose, K. Martins, M. Terrado, and E. M. Bennett. 2013. Variability in ecosystem service measurement: a pollination service case study. Frontiers in Ecology and the Environment 11 (8):414-422. http://dx.doi.org/10.1890/120189

Mouchet, M. A., P. Lamarque, B. Martín-López, E. Crouzat, P. Gos, C. Byczek, and S. Lavorel. 2014. An interdisciplinary methodological guide for quantifying associations between ecosystem services. Global Environmental Change 28:298-308. http://dx.doi.org/10.1016/j.gloenvcha.2014.07.012

Nowak, D. J., and D. E. Crane. 2002. Carbon storage and sequestration by urban trees in the USA. Environmental Pollution 116(3):381-389. http://dx.doi.org/10.1016/s0269-7491(01)00214-7

O’Connell, B. M., E. B. LaPoint, J. A. Turner, T. Ridley, S. A. Pugh, A. M. Wilson, K. L. Waddell, and B. L. Conkling. 2014. The forest inventory and analysis database: database description and user guide version 6.0.1 for phase 2. USDA Forest Service, Washington, D.C., USA. [online] URL: http://www.fia.fs.fed.us/ library/database-documentation/

Penman, J., M. Gytarsky, T. Hiraishi, T. Krug, D. Kruger, R. Pipatti, L. Buendia, K. Miwa, T. Ngara, K. Tanabe, and F. Wagner. 2003. IPCC: good practice guidance for land use, land-use change and forestry. Institute for Global Environmental Strategies, Kanagawa, Japan. [online] URL: http://www.ipccnggip.iges.or.jp/public/gpglulucf/gpglulucf contents.html

Pickett, S. T. A. 1989. Space-for-time substitution as an alternative to long-term studies. Pages 110-135 in G. E. Likens, editor. Longterm studies in ecology: approaches and alternatives. SpringerVerlag, Berlin, Germany. http://dx.doi.org/10.1007/978-1-4615-7358-6_5

Qiu, J., and M. G. Turner. 2013. Spatial interactions among ecosystem services in an urbanizing agricultural watershed. Proceedings of the National Academy of Sciences 110 (29):12149-12154. http://dx.doi.org/10.1073/pnas.1310539110

$\mathrm{R}$ Development Core Team. 2014. R: a language and environment for statistical computing. R Foundation for Statistical Computing, Vienna, Austria. [online] URL: http://www.R-project.org

Raudsepp-Hearne, C., G. D. Peterson, and E. M. Bennett. 2010. Ecosystem service bundles for analyzing tradeoffs in diverse landscapes. Proceedings of the National Academy of Sciences 107 (11):5242-5247. http://dx.doi.org/10.1073/pnas.0907284107

Renard, D., J. M. Rhemtulla, and E. M. Bennett. 2015. Historical dynamics in ecosystem service bundles. Proceedings of the National Academy of Science 112(43):13411-13416. http://dx.doi. org/10.1073/pnas.1502565112

Ruesch, A., and H. K. Gibbs. 2008. New IPCC tier-1 global biomass carbon map for the year 2000. Oak Ridge National Laboratory, Oak Ridge, Tennessee, USA. [online] URL: http:// cdiac.ornl.gov/epubs/ndp/global_carbon/carbon_documentation. $\underline{\mathrm{html}}$
State of Washington, Department of Ecology. 2013. Funding guidelines state fiscal year 2015: water quality financial assistance. State of Washington, Department of Ecology, Water Quality Program's Financial Management Section, Olympia, Washington, D.C., USA. [online] URL: https://fortress.wa.gov/ecy/publications/ SummaryPages/1310041.html

Tomlinson, M. J., S. E. Gergel, T. J. Beechie, and M. M. McClure. 2011. Long-term changes in river-floodplain dynamics: implications for salmonid habitat in the Interior Columbia Basin, USA. Ecological Applications 21(5):1643-1658. http://dx.doi. org/10.1890/10-1238.1

Tomscha, S. A., and S. E. Gergel. 2015. Historic land surveys present opportunities for reconstructing frontier settlement patterns in North America. Landscape Ecology 30:2013-213. http://dx.doi.org/10.1007/s10980-014-0124-X

Turner, K. G., M. V. Odgaard, P. K. Bøcher, T. Dalgaard, and J.C. Svenning. 2014. Bundling ecosystem services in Denmark: trade-offs and synergies in a cultural landscape. Landscape and Urban Planning 125:89-104. http://dx.doi.org/10.1016/j. landurbplan.2014.02.007

Ulrich, R. S. 1986. Human responses to vegetation and landscapes. Landscape and Urban Planning 13:29-44. http://dx. doi.org/10.1016/0169-2046(86)90005-8

United States Department of Agriculture (USDA). 2006. Compressed county mosaic 1-m color orthophoto for Chelan County. USDA-FSA Aerial Photography Field Office, FSA National Agriculture Imagery Program (NAIP), Salt Lake City, Utah, USA.

Van Deusen, P., and L. Heath. 2014. COLE web applications suite. NCASI and USDA Forest Service, Northern Research Station, Newton Square, Pennsylvania, USA. [online] URL: http://www. ncasi2.org/COLE/

Villamagna, A. M., P. L. Angermeier, and E. M. Bennett. 2013. Capacity, pressure, demand, and flow: a conceptual framework for analyzing ecosystem service provision and delivery. Ecological Complexity 15:114-121. http://dx.doi.org/10.1016/j.ecocom.2013.07.004

Wu, J., Z. Feng, Y. Gao, and J. Peng. 2013. Hotspot and relationship identification in multiple landscape services: a case study on an area with intensive human activities. Ecological Indicators 29:529-537. http://dx.doi.org/10.1016/j.ecolind.2013.01.037 